\title{
An Anatomy of a Female Body: Pregnancy, Technology and Literary Imagination Through Jessie Greengrass's Sight
}

\author{
Kanmani C. S. Arumugam and Marie Josephine Aruna \\ Kanchi Mamunivar Institute for PG Studies and Research (Autonomous), Puducherry, India
}

\section{ABSTRACT}

This Paper attempts to create an interdisciplinary space in productively analysing the past and futuristic medical practice of gynaecology through literary context giving scope to health humanities. With reference to Jessie Greengrass's insightful work, Sight, the paper tends to discuss the contemplative journey of what happens inside the unnamed narrator's body. Jessie Greengrass's intuitive knowledge in medical history, eventually results in giving a page-to-page inward transformation of a pregnant body into an individual self of the narrator. With an extraordinary imaginative scrutiny of the earlier centuries of scientific developments and the psychological state of the psychoanalysts themselves, Greengrass tries to exhibit the liberty that literature takes to describe even the most delicate definitions of techno-scientific fields as lively experiences which creates stronger impact even in a common reader's minds.

\section{KEY WORDS: AGORAPHOBIA, BABY BREACH, HEALTH HUMANITIES, JESSIE GREENGRASS, LITERATURE AND MATERNITY CARE.}

\section{INTRODUCTION}

Literature and science, both are the disciplines that demand mental faculties in individual lives and in academics. They are the outcome of one's observation and expressing them, but in different points of view and as different discourses (Quadeer, 2016). Literature and science are interconnected in the modern academic coalescence and are virtually synonymous but the methods of approach in the present time is different (Rousseau, 1981) (Vlahakis et al., 2014). Medical realm limits itself with vague representation of data, whereas, Health humanities urges to amalgamate scientific knowledge with empathetical life experiences. In explaining the unique influence of these disciplines on one another, Quadeer brings in the cognitive comparations between literature and science as creative imagination and curious ingenuity of an individual's expression of thoughts respectively. The study exercises, i) The documentation of medical history in the novel; ii) Insightful journey of the narrator, where

Biosc Biotech Res Comm P-ISSN: 0974-6455 E-ISSN: 2321-4007

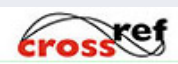

Identifiers and Pagination

Year: 2021 Vol: 14 No (8) Special Issue

Pages: $115-120$

This is an open access article under Creative
Commons License Attribn 4.0 Intl (CC-BY).
DOI: $h t t p: / / d x$.doi.org/10.21786/bbrc/14.8.28

Commons License Attribn 4.0 Intl (CC-BY).
DOI: $h$ ttp://dx.doi.org/10.21786/bbrc/14.8.28 she narrates iii) The growth of anatomy from the past to the present.

Interdisciplinary approach to various subjects nourishes the specified field with the better understanding of the literacies. It is a sophisticated engagement of integration of various disciplines, where one reasoned methodological perspective is acquired from other possible disciplines. This study brings out the interdisciplinary approach of two similar but protracted fields of health and well-being and its influence on and connections to literature, one evolving purely out of imaginative artistry and the other simply out of cognitive curiosity. The disproportionate representation of natural sciences in literary history announces the urge of new studies like Bioethics, applied sciences, animal studies, food studies, literature and Anthropocene, digital humanities, health humanities and so on. This study analyses the representation of scientific discovery of Wilhelm Rontgen's X-ray, emergence of modern surgery, ancient medical practices and their failures, psychoanalytical works and personal life of Sigmund Freud, early medical illustrators, the anatomy of pregnant bodies and the inward psychological apprehension of the unnamed pregnant narrator of the novel, Sight. frameworks of that subject in connection with all possible advancements and practices such as the accidental

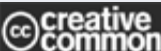

Article Information

Received: $11^{\text {th }}$ Apr 2021

Accepted after revision: $24^{\text {th }}$ June 2021 
Health Humanities, solidifying itself for four decades, is an integrated "epistemological multicompetence" that describe the irreconcilably different but united by the fundamental framework of partakers' "emergent capability to toggle between multiple disciplines, arts and humanities particularly, in health-related" studies (Costa et al., 2020; mdpi.com; Savelyeva Anna, 2019), engrossing fields counting science that demands emphatic human-centred interdisciplinary analysis (Mayhew, 2020). This influential study beyond academic and clinical specialities challenge the tradition that medicine and health care are understood and accomplished focusing "on human wellness throughout the life cycle across different times and spaces" (Leeuw et al., 2018: Savelyeva Anna, 2019).

The anatomy of human body, in two ways, (microscopic and macroscopic), generally describes the structures and functions of the patterned cells to tissues to bones and organs of a living being, and indicates "anatomical non-obsessive inconsistencies known as varieties which should have the capacity to be perceived" (Longdom. org). "The study of medicine has been centred on basic scientific discovery and innovative technology that can improve diagnostics, treatment, and survival for patients" says a paper on "'Health Humanities': Medicine and the Future of Humanities" (Savelyeva Anna, 2019). A 2015 review of Maria Vaccarella on "Health Humanities: Paul Crawford, Brian Brown, Charley Baker, Victoria Tischler and Brian Abrams", clarifies that the "engaging in metasyntheses could also facilitate the emergence of a new, more cogent academic role for humanities interested in health-related issues, whom the authors describe as often wary of pushing their ideas into practice" (The Reading Room, 2015).

A 2016 detailed paper of John Sharkey on "BioTensegrity: A New Anatomy for the 21st Century?", presented at an international conference on Anatomy and Physiology, Birmingham, UK, clearly hints that the field of science and researches had reached to an advancement of "bio tensegrity", an emerging discipline investigating a new terminology of "dissections of 'soft tissue' to 'soft matter' for better understandings of the mechanisms of human movement and chronic pain while providing new anatomical knowledge and awareness leading to less invasive surgical and non-surgical therapeutic interventions." (Sharkey, 2016). Moreover, medical advancement is such that, the habitudes of artificial intelligence "establish clinical correlations and insights via developing associations and patterns from the existing database of information" (Amisha et al., 2019), translating the provided database and flowcharts. But a mere inclination of the careers of STEM subjects (covering every subject falling under Science, Technology, Engineering and Mathematics) and the advancements in those disciplines necessitate the understanding of the ground in which they intend to prove their mastery. Unmitigatedly they all are going to handle humankind or other species, living or dead, in some way or the other with a skilful excellence of scientific encounters.
Furthermore, fictional narratives that integrate medical humanities are only handful that include, House of God (1978), The Doctor Stories (1984), The Man Who Mistook His Wife for a Hat and Other Clinical Tales (1985), Probably Nothing (a memoir) (2016), and so on. Those narratives are mostly the fictional reflections of personal experiences of surgeons and specialists, who find humanity beyond science with some deficiency.

But with an interdisciplinary approach, Jessie Greengrass, has exceptionally accomplished the mental state of a pregnant woman who imagines the mental state of her mother with ailments, (dead a decade ago). She then treks back to her childhood summer holiday memories of her psychoanalyst grandmother. The narrator sees her granny's diagnosis and findings as lively that her granny's first client was, herself, every day. She further travels backwards to the eighteenth-century societies where people discovered and invented medical accessories and machines, the first failures of their first attempts of inventing and using medical apparatus, surgery, anatomy, caesarean deliveries and their failures which had helped in the emergence of new developments of the present age. She therefore records her experiences of every trimester that led to a tiresome labour, giving birth to a malnourished baby girl, narrowly escaping c-section due to baby breech. She recites, "Science was once a form of worship, this stripping back of layers away to wonder at the fierce complexity of god's work the duty of created to creator" (135).

Sight and the Documentation of Medical History: The narrator starts her narration with the significant event of the 1895's discovery of X-ray and imagines about the psychoanalytic treatment of her grandmother and compared her life of Anna, daughter of the famous psychoanalyst Sigmund Freud, who later became the protector of his phenomenal works even before his disciples did. In the due course the narrator also records the earlier attempts of the anatomist brothers and professional rivals, William and John hunter and their medical illustrator Jan Vann Rymsdyk's artistic penning down of delicate details of live and dead pregnant uteruses and foetal features into documents. Greengrass has given a literary touch to the sensitive complications of Medicine.

The unnamed pregnant narrator visualises her unnamed first daughter's future growth connecting her's to her unnamed dead mother whose "physical closeness was an emotional distance" (11). In the due course she artistically documents her imagination of the insides of a body to the history of accidental discovery of X-ray in 1895 as, "shadowed outline, leaving the image of a substrate world spread out across a photographic plate, a catalogue of metal bone..." (3), whereas science defines X-ray as painless, aggressive detection of "electromagnetic radiation that differentially penetrates structures within the body and creates images of these structures on photographic film or a fluorescent screen" to diagnose the internal disturbances of the body (healthofchildren.com). she then imagines of the mental conditions of her mother 
during her final days. The narrator's mother complains of ceasing of dreams and the narrator imagines this with Freud's hypotheses of how dreams are associated with the psyche of human and the cruel effects of medication which requires "interpersonal continuity" such as trust and holistic relationships in patient's care(Ridd et al., 2009) , and then talks about the effects of radiotherapy, a "fortnightly inconvenience" (9) and the "the tangles of tubes and monitors, the drips and beeps,..." (10) and a "barrow's shape beneath the sheets, her hair lost on one side where surgery had stripped her skin" (90).

Imagining her childhood days in her grandmother's house the narrator gives us the opportunity to glide through Sigmund Freud's personal life. Her grandmother DR. K was a psychoanalyst and in her views the anatomy of body is defined as "far from being the container and concealer of (my) mind had become it's compulsive betrayer and (I) wished that instead of entering the consulting room we might go...." (78). Whereas in science anatomy is defined as something that "describes the structure and location of the different components of an organism to provide a framework for understanding. Human anatomy studies the way that every part of a human, from molecules to bones, interacts to form a functional whole" (lumenlearning.com). And with technological advancements anatomy tends "to see what previously remained invisible in the anatomical body, and "the anatomical gaze" reaches beyond the strictly defined discipline of anatomy ("Summary", Sellars, 2015), with "Stripped of skin, we can see the body's fascinating underlying architecture." ("Summary", Huskey, 2017).

In Dr K's views, the analyst, is not "a tour guide leading their clients through those vast and vaulted galleries the cloisters of the mind and nor is it their task to point out shadows but rather they must provide ... instruction in the mechanics of such shadows' investigation" (80). Dr. $\mathrm{K}$. being a first client to herself wrote diaries, pointing out her previous day's experiences in which both the doctor and analysand travel through decades of their past and present "to peel away the obscuring layers the muddying cross-currents of desire..." (81). At her granny's residence, the narrator happens to read the works of Sigmund Freud and analyse all her "thoughts and actions, (my) hidden wants, the ripples of (my) mind across (my) face (my) skin, should be considered little more than symptom while the act of examination itself was sacrosanct" (83).

There she reads about Freud's analysand Little Hans, (Herbert Graf) and equates her state from the little boy's contour whose, "trust had been opened like a nut split to see what mechanism it was that made it grow falling into step beside his analyst father who were from being the negation of fear was now its subject" (91). Along with Little Hans, Freud himself had become his daughter Anna's analyst, working with Melanie Klein, Jung, Karl Abraham (93). The narrator describes life as "shoreless fluidity" and herself "adrift inside it". She describes Freud's disturbed childhood as "the settled silt was once more muddy water. Memories long ignored began to surface the sight of his mother naked in the sleeper compartment" (101), his rival attitude towards his brother gave him "a neurotic experience with odd states of mind not intelligible to consciousness cloudy thoughts and veiled doubts, with barely here and there a ray of light" (101). So, he started to analyse himself first and "Such techniques of manipulation - towards a higher scientific aim - make Freud's case studies extremely evocative, contributing to their ongoing appeal to psychoanalysts, as well as readers in the humanities more generally" (Lang \&t Afsharian, 2017).

Greengrass comparing the disturbed life of Freud and his truncated interpretations of dreams with Dr. K's which led to her own revelations, makes the narrator to describe as, "her mind turned in words concentrated on those phenomena are accessible only to herself" (103). The passages of the novel clearly situates the diffusion of medical science and humanities, as she recites, "true self analysis is impossible else there would be no illness" (104) and Freud's words merges with her own childhood life, "I was alone with my grandmother and the flat and the health"(86); being a child of absent father (a theory that conceptualises to study the consequences in child's sexual growth), she writes, "I assumed his absence, tried not to seem resentful of his presence" (112).

The narrator shows her fear of getting children "the overwhelming fear" and her awareness as "like falling into endless water and with it the attendant organising understanding that what success looks like is being left behind.... Unthinkable perfection of a preserve present" (127). Her emotional state disturbs the baby inside too that in the starting of her third trimester she feels sick of nauseating sensation. So, she visits the local museum and Freud's native place. She talks about the history of early eighteenth-century anatomists, William Hunter assisted by his brother at the Convent Garden in 1748, who dissected the dead corpse's uterus, the anatomy of the gravid uterus exhibited in "the delicate operation of this unnamed women's unpeeling: the careful parting of skin and muscle like the drawing back of heavy curtains to give sight of the horizon beyond; the injection of blood vessels with ear mixture of wax and dye" (146).

The medical illustrator who assisted the brothers penned down every detail of the woman's abdomen and the baby's features. The artistic talent of the illustrator was so perfect that it was "only of reproduction, eye to hand: the surface of things stretched across this paper each fold of skin each has the shadow of a cheek, finger nails and eyelids closed" (151). It was the time, the pioneers of anatomy and surgery failed in their attempts. The narrator tours to the early life of the Hunter brothers, ripping the dead animals' parts, later treating the wounded soldiers. In 1767, Martha Rhodes, a 23-yearold alive pregnant lady who had been retreated by one of them. None of the attendees have had performed that operation before, "A gaggle of men physicians and surgeons gathered like jostling birds around the table on which Martha lay, her head resting on a pillow and her legs hanging down..." (156). 
The treatment needed the dosage of opium, lacked hygiene because the concept of hand washing introduced by Lister had happened only in the next century, the narrator imagines "holding in the mass of intestine which spilled out into the resulting space.... Stitched the wound shut and when the needle pierced Martha's skin, she cried out.... died five hours later ... baby survive two days" (158), unlike the modern medications like "tocolytic drugs; vibroacoustic stimulation; regional analgesia; amnioinfusion and systemic opioid drugs" (Cluver et al., 2012), which as a deficiency in the medical evolution, she compares this to the present day's sonograph which could capture the delicate details of the uterus. Through this she undergoes the inconveniences of her trimesters, with her doctor's explaining her body condition like "an object in the space between us predictable and mundane and of which he having more experience was better judge and all I did was carry it about" (189).

Insightful Journey Of A Pregnant Body: In the recent years, there has been a need of anticipating the mother-daughter relationships theoretically with a comprehension of pathological, psychoanalytic therapies, in contrast to conventional patriarchal parent-child relationships (Diane K. Shrier, 2016). Greengrass explains the experience of pregnancy, the motherhood and of the mother-baby bond very beautifully, as "The epigenetics of comfort" and through the narrator's sleepless nights with sickness and piles of laundry to wash, and a big list of shopping, living with those "tiny-interludes" (155), "which ebb and flow like tides" (124). The closeness and the distance she felt in her mother and grandmother is felt with her baby too. Hence, she recalls, "The infants and the mother's coextensive but not conjoined systems... the line between us was a cell's breadth across but still it held as back from falling into one another and we were not the same" (125).

She also expresses the process of growth as, "a transformative process a passage through the refiner's fire during which one would be rendered down into capability of strength" (112). Before her first pregnancy she deemed her body as a "kind of tool, a necessary mechanism, largely self-sustaining which, unless malfunctioning", was obeying her instructions, she could abruptly control her frolic body, which she, during pregnancy, deems "as more than a conceit and betrayal" (161). With conception her house-like body "has been gutted and rebuilt ... No longer singular" (154). Her body is compared with those of Hunter's and Rymsdyk's patients not as "impassive, single entity" but as "an urn to be excavated" of its hidden treasures of "heavy organs, lungs, lymphatic system, the tree - like pattern veins make the chambers of the heart" (162).

The narrator prelects about the ruthless ancient treatment methodologies, involving "quackery, alchemy and religion" (162), dosing with opium, pulling the tooth with pliers, passed down the generations without the knowledge of anatomy or public practice, and juxtapose it to the modern advancements of sonographs. Those were the time when medicine has not become the profession.
A domestic appearance can be seen with those pioneers and specialists worked "Securing exclusive licensing restrictions on practice, limiting the dispensing of prescription medications, obtaining wider public support for elite medical education, and related professional prerogatives all contributed to this individual persuasive influence" (Crenner, 2005).

The Sonographer of the narrator creates "diagnostic images of various anatomical structures for interpretation by a physician" (Findlay.edu), passes the transducer around her belly" when she went "staring" to catch hold of the sight of the baby across her shoulder at the monitor and sees, "the mass of grainy shadows" of her child on the screen, "and that it was ours, that it was there with us, not merely as a ghost or imitation but as something present in the room-as though the truth of it could be drummed into me by repetition" transmuting "its border coextensive" within herself "by the act of site from subject to object". She finds this as a wonder and compares to the celestial adventure of 1665 Huygens's Probe landed with extra thirty minutes of "battery life", taking pictures of nitrogen swathed Titan, a moon of Saturn and of Mars later to find that all the three, similar, agnate, familiar yet strange "as if from dust or static, ill-formed communications of ghosts, were in their strangeness absolute", and while the other two are miles away thereby becoming irresolvable but as far her baby is concerned, it " turned its aquatic loops in a space which I contained but couldn't reach" (140-144).

From Past To The Present: A bivariate study on maternal distress equates the effect of environmental, psychological and genetic disturbances experienced during gestational period, reflecting as poor mental health and similar ramifications in mother and child (Prady et al., 2013). The narrator pronounces her inconvenience during her "first numb weeks when balance is precarious, the tumbling rush to interpret a new born's needs" (131) "Unexpected and abrasive loneliness" (132), like a mind never listening to her body and body malfunctioning her commands and was like a "house with one wall open to the wind" (133). She hated waiting outside the consulting room, for the "times and spaces of waiting" are "often-protracted moments they produce, have potential to affirm our humanity" (Leeuw et al., 2018).

With broken sleeps and tangled sickness, becoming "coextensive with consciousness" (155), she suffered from Agoraphobia, "a terror that if took the baby outside someone would become in capable and able to protect or from some catastrophe" (174). This contrasts with delivering the girl baby as "daughters' perceptions of the external world are constituted, and indeed haunted, by their contradictory feelings for their mothers, their first, discarded love-objects" (Molloy, 2014). Her exhaustion accrued her fear thereby causing baby breech accepting her own failure to marshal (my) flesh and control (my) unborn child...(I) hadn't even known existed and couldn't recognise although I too had seen it on the screen, that pattern of dark and light which the inside of (my) whole body made - we can book you in for an ECV and try 
to turn the baby manually. It's a bit uncomfortable and there is small risk ... (188), so She comfortably accepts her surrender and she agrees for an ECV (External Cephalic Version) to physically turn the breeched baby.

Greengrass's mastery in weaving literature with the needle of technology is proven through her documentation of obstetric emergency. It arises commonly in women with inadequate health or due to anxiety or stress or fear of premature labour or disturbed psyche which demands , "affective containment that is strengthened with breastfeeding in an indissoluble and close bond called "mother-child dyad"'(Rosati et al., 2019).The narrator is already distressed by her mal nourished first daughter, with " bluish skin stretch tight across the skull, the line of the vertebrae showing along her back like credit pearls beneath a cotton sheet" (154). So, this time she has to listen to her gynaecologist, as baby breech elongates the gestational age where baby's bottom is seen first and specialists try to physically turn the baby (ECV) to almost avoid c-sections during inadequate maternal health care with, "selective use of tocolysis, the role of regional analgesia, foetal acoustic stimulation, amnioinfusion and the effect of intravenous or oral hydration prior to ECV., Although randomised trials of nitro-glycerine are small, the results are sufficiently negative to discourage further trials" (Cluver et al., 2012) (Longdom.org).

The narrator confesses, the Obstetrician pushed my unborn daughter round through the skin of my stomach forcing her to turn by 180 degrees...I sat for another hour attached to the monitor; the baby was fine,...I lost track then ... the people who came and went about me, of the appointments attended, the waiting rooms in habited... My blood pressure was taken often...I was warned about vision changes headaches swelling of the hands or feet ...And then a doctor breaking my waters with a kind of pen and oxytocin drip; the feeling that my body was turning itself inside out... and how I lay and begged calling out for something to be done (191-193). Finally giving birth to a girl baby, she wonders the reason for the new born's crying "she starts to cry in new-borns wail of bleak surprise and we do not know the reason but must try, somehow, to find it out" (193), where science still working on the hours beyond their birth as traumatic bruise or sore ( Luis, n.d.) and talk about neonatal refluxes and their APGAR (activity, pulse rate, grimace, appearance and respiration) scores but not on exact reason for neonatal infants' crying.

\section{CONCLUSION}

Common expressions in the jargon of medical societies like - "It's a medical miracle", "These leaflets would explain the disease", "lets trust in God", "nothing is sure until 48 hours", "it's a rare occurrence which cannot be explained" - discerns the debilitated condition of Science though it had attained a giant development. Technological advancements incorporate artificial intelligence, and touches almost every preposterous complication, turn it to an expedient and feasible case. Yet it has some setbacks in certain conditions. As Savelyeva puts that "the mechanistic perfection of science and medicine is only limited by the imperfection of human skill" (2019) and they are far from the scientific leach off. The analysts or the specialists see everything under the microscope as only a subject of study irrespective of their species' hierarchy, dead or alive. For an analyst, everything, be it a rodent; a clone; a pregnant woman or a corpse, they are all the same, an object to be studied, analysed, and reported. "It takes to literally burn all peripheries to shape a veritable piece, valid enough to be accepted in either literature or science, and hence, both disciplines are tyrannically real in their own realms" (Quadeer, Sofia Arslan, 2016).

Greengrass, who is no way connected to medical realm, except philosophically approaching the medical issues, takes up the lapses in science, which cannot interpret human emotions and feelings in comprehensible words, unless and otherwise, as a data of neural inclination towards the outward situation. With an escalated insight of going inside of human minds and travelling back to the history and imagining the life, death and after death experience of people, she delivers a "more sensitive, holistic, ethically informed, medical education" (Prabhu, 2019) strongly, and has fathomed the incomprehensible experiences in her own ingenuities and erudition inviting Sigmund Freud, William Hunter and many such medical pioneers and visualises how they failed in their lifetime but paved way to new emergence of medical upsurge.

This kind of hybridization is the need of the hour as the globe is facing an obnoxious situation. Interdisciplinary approach, particularly the study through health humanities helps understanding multiple perspectives of a particular sphere, eventually, to 'synthesise' minds. Interdisciplinary subjects explore and integrate divergent themes and commission the new emergence of ideas (Golding, 2009). Greengrass has deliberately dedicated this insightful work to health humanities, "to explore the complex meanings that get attached to health, illness, disease, disability, and therapeutic encounters" (Prabhu, 2019). Being a woman writer, Greengrass considers the psychological, and medical issues, which are given less attention, regarding women well-being, and with her explorative work, she appeals for more reconnaissance of literary works in the field of health humanities.

\section{REFERENCES}

Amisha, Malik, P., Pathania, M., \&t Rathaur, V. K. (2019). Overview of artificial intelligence in medicine. Journal of Family Medicine and Primary Care, 8(7), 2328-2331. https://doi.org/10.4103/jfmpc.jfmpc_440_19

Cluver, C., Hofmeyr, G. J., Gyte, G. M., \& Sinclair, M. (2012). Interventions for helping to turn term breech babies to head first presentation when using external cephalic version. The Cochrane Database of Systematic Reviews, 1, CD000184. https://doi. org/10.1002/14651858.CD000184.pub3

Costa, M., Kangasjarvi, E., \&t Charise, A. (2020). Beyond empathy: A qualitative exploration of arts and humanities in pre-professional (baccalaureate) health 
education. Advances in Health Sciences Education. https://doi.org/10.1007/s10459-020-09964-Z

Crenner, C. (2005). Private Practice: In the Early Twentieth-Century Medical Office of Dr. Richard Cabot. Baltimore: Johns Hopkins University Press., doi:10.1353/book.60318

Golding, Clinton. (2009). "Integrating the disciplines: Successful interdisciplinary subjects”. http://www.cshe. unimelb.edu.au/

Huskey, S. (2017). The Skeleton Revealed: An Illustrated Tour of the Vertebrates. Johns Hopkins University Press. https://muse.jhu.edu/book/57048

Jeremy De Chavez. (n.d.). Dreaming of Animals: The Animal in Freud's Analysis of a Phobia in a Five-year Boy and History of an Infantile Neurosis | Rupkatha Journal on Interdisciplinary Studies in Humanities. Retrieved July 6, 2020, from http://rupkatha.com/ freuds-infantile-neurosis/

Leeuw, S. de, Donovan, C., Schafenacker, N., Kearns, R., Neuwelt, P., Squier, S. M., McGeachan, C., Parr, H., Frank, A. W., Coyle, L.-A., Atkinson, S., El-Hadi, N., Shklanka, K., Shooner, C., Beljaars, D., \&t Anderson, J. (2018). Geographies of Medical and Health Humanities: A Cross-Disciplinary Conversation. GeoHumanities, 4(2), 285-334. https://doi.org/10.1080/2373566X.201 8.1518081

Mayhew, E. (2020). 'A higher form of listening': A commentary on 'the human bodies of World War II: beyond the battlefield.' Medical Humanities. https://doi. org/10.1136/medhum-2019-011676

Prabhu, G. (2019). Medical themes in a literature classroom: An alternate perspective on Medical Humanities pedagogy in India. Indian Journal of Medical Ethics, IV(1), 35-38. https://doi.org/10.20529/ IJME.2018.060

Prady, S. L., Pickett, K. E., Croudace, T., Fairley, L., Bloor, K., Gilbody, S., Kiernan, K. E., \&t Wright, J.
(2013). Psychological Distress during Pregnancy in a Multi-Ethnic Community: Findings from the Born in Bradford Cohort Study. PLOS ONE, 8(4), e60693. https:// doi.org/10.1371/journal.pone.0060693

Quadeer, Sofia Arslan. (2016). Literature vs Science: Each discipline exerts a unique influence on the other. Nation.Com. https://nation.com.pk/02-0ct-2016/ literature-vs-science-each-discipline-exerts-a-uniqueinfluence-on-the-other

Ridd, M., Shaw, A., Lewis, G., \& Salisbury, C. (2009). The patient-doctor relationship: A synthesis of the qualitative literature on patients' perspectives. The British Journal of General Practice : The Journal of the Royal College of General Practitioners, 59, e116-33. https://doi.org/10.3399/bjgp09X420248

Rousseau, G. (1981). Literature and Medicine: The State of the Field. Isis, 72(3), 406-424. Retrieved July 5, 2020, from www.jstor.org/stable/230258

Savelyeva Anna. (2019). "Health Humanities": Medicine and the future of Humanities | FHI Health Humanities Lab (HHL) at Duke University. https://sites.fhi.duke.edu/ healthhumanitieslab/health-humanities-medicine-andthe-future-of-humanities/

Sellars, N. (2015). The Optics of Anatomy and Light: A Studio-based Investigation of the Construction of Anatomical Images. Leonardo, 48(5), 481-481.

The Reading Room: A review of "Health Humanities." (2015, May 5). Medical Humanities. https://blogs.bmj. com/medical-humanities/2015/05/05/the-readingroom-a-review-of-health-humanities/

Villazan, Luis. (n.d.). Why do New Born Babies Cry? BBC Science Focus Magazine. Retrieved July 8, 2020, from https://www.sciencefocus.com/the-human-body/ why-do-newborn-babies-cry/

Vlahakis, G. N., Skordoulis, K., \&t Tampakis, K. (2014). Introduction: Science and Literature Special Issue. Science \& Education, 23(3), 521-526. https://doi. org/10.1007/s11191-013-9601-X 